\title{
Fluorescent Anion Receptor with Two Methylene Bridged Bis-imidazolium Ring on Anthracene
}

\author{
Sungjae In and Jongmin Kang* \\ Department of Applied Chemistry, Sejong University, Seoul 143-747, Korea. *E-mail: kangjm@sejong.ac.kr \\ Received May 4, 2005
}

Key Words : Bis-imidazolium ring, Fluorescent anion receptor

Artificial receptors for selective anion recognition is an area of intensive investigation as anions play a fundamental role in a wide range of chemical and biological process. ${ }^{1}$ Receptors based on guest anion induced changes of color or fluorescence seems to be attractive due to their high sensitivity and low detection limit. ${ }^{2}$ In many cases, hydrogen bonds are utilized as anion recognition element as host-guest complementarity could be achieved from the directionality of hydrogen bonds. The orientation of hydrogen bonds can differentiate anionic guests with different geometries. While most of hydrogen bond anion receptors utilize $\mathrm{N}-\mathrm{H}---\mathrm{X}^{-}$or $\mathrm{O}-\mathrm{H}---\mathrm{X}^{-}$hydrogen bonds, ${ }^{3}$ 1,3-disubstituted imidazolium groups are recently introduced as new anion binding hydrogen bond moiety by forming $(\mathrm{C}-\mathrm{H})^{+}-\mathrm{X}^{-}$hydrogen bonds between $\mathrm{C}(2)-\mathrm{H}$ in imidazolium rings and the guest anion. Depending on the spatial arrangement of 1,3-disubstituted imidazolium groups, halide, ${ }^{4}$ dihydrogen phosphate, ${ }^{5}$ dicarboxylate, ${ }^{6}$ sulfate $^{7}$ selective receptors have been reported.

To extend the scope of imidazolium anion receptor, we have designed and synthesized the receptor $\mathbf{1}$, bearing two methylene bridged bis-imidazolium ring on 1,8-positions of anthracene. For the synthesis of anthracene receptor 1, methylene bridged bis-imidazole 2 was synthesized in 64\% yield from the reaction of imidazole and bromochloromethane. Then the bis-imidazole 2 was reacted with 0.3 equivalents of ethyl bromide to give imidazolium ion $\mathbf{3}$ in $37 \%$ yield. This intermediate was refluxed in acetonitrile for 4 hours with 1,8-bis(bromomethyl)anthracene. Anion exchange with ammonium hexafluorophosphate gave receptor 1 bearing two methylene bridged bis-imidazolium ring on 1,8-positions of anthracene (Scheme 1). All compounds were characterized by ${ }^{1} \mathrm{H}$ NMR, ${ }^{13} \mathrm{C}$ NMR and high resolution mass spectrum.

The complexation abilitiy of receptor 1 to the halides was measured by standard ${ }^{1} \mathrm{H}$ NMR titration experiments in $10 \%$ DMSO- $\mathrm{d}_{6}$ in $\mathrm{CD}_{3} \mathrm{CN}$ using a constant host concentration(4 $\mathrm{mM}$ ) and increasing concentrations of anions (1-10 equivalents). The chemical shift data were analyzed by EQNMR. ${ }^{8}$ The addition of tetrabutylammonium halide salts to the solution of 1 in $10 \%$ DMSO- $\mathrm{d}_{6}$ in $\mathrm{CD}_{3} \mathrm{CN}$ resulted in downfield shifts in two $\mathrm{C}(2)$ proton peaks of imidazolium ring. In case of iodide ion, two $\mathrm{C}(2)$ protons originally resonating at $\delta=9.10$ and 9.05 were shifted to $\delta=9.50$ and 9.47 upon the addition of 5 equivalents of iodide ion, which indicates that all $\mathrm{C}(2)$ protons are involved in binding events.
Assuming 1:1 binding stoichiometry, the association constant calculated from the chemical shift change of $\mathrm{C}(2)-$ $\mathrm{H}$ of imidazolium ring was $103 \pm 11$.

The anthracene receptor 1 displayed strong fluorescence emission in $10 \%$ DMSO in acetonitrile solution as shown in Figure 1. The excitation and emission wavelength were 365 $\mathrm{nm}$ and $413 \mathrm{~nm}$ respectively. The associations between the anthracene receptor $\mathbf{1}$ and spherically shaped halides were investigated by fluorescence titration. The fluorescence change of the receptor 1 was monitored in $10 \%$ DMSO in acetonitrile. The intensity of emission spectrum from $10 \mu \mathrm{M}$ solution of the anthracene receptor $\mathbf{1}$ decreased as the concentration of tetrabutylammonium halides salts was increased, which indicates the association between the receptor 1 and halides. The stoichiometry between host and guest was determined by fluorescence Job plot, which
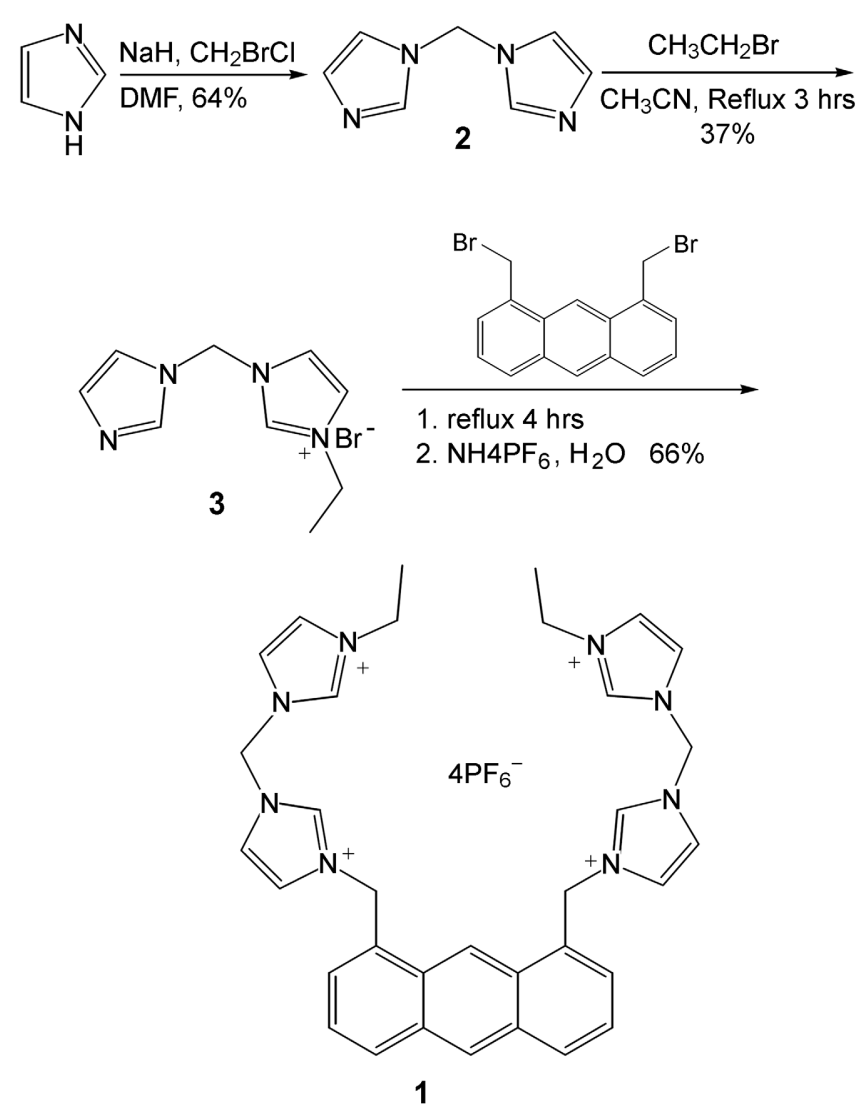

Scheme 1. The synthetic procedure for the anion receptors 1 . 


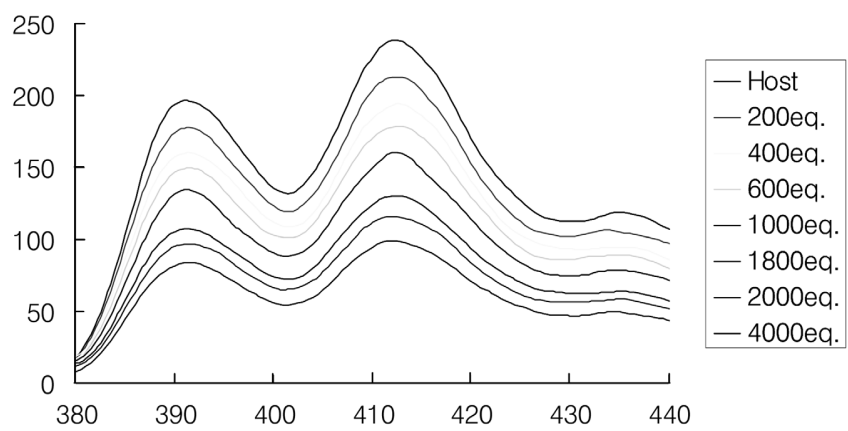

Figure 1. The change of fluorescence spectra in the receptor 1 when tetrabutylammonium iodide was added.

showed evident $1: 1$ stoichiometry. $^{9}$ (Figure 2) A BenesiHildebrand plot $^{10}$ by use of change in the $413 \mathrm{~nm}$ fluorescence intensity gave association constants. From the experiments, the association constants for iodide is found to be $80 \pm 5.0$ which is quite similar value calculated from ${ }^{1} \mathrm{H}$ NMR titration. For other halides, the association constants were calculated $140 \pm 18$ for bromide, $330 \pm 13$ for chloride and $980 \pm 17$ for fluoride. Molecular modeling showed that the anion receptor 1 has a concave structure. The four $\mathrm{C}(2)-$ $\mathrm{H}$ in imidazolium rings form a concave cavity and point to the anion located at the center of cavity. We noted that the size of cavity in receptor $\mathbf{1}$ is flexible. While the four imidazoles are located close each other, the receptor 1 can bind halides. The energy minimized structure of receptor 1 and iodide is shown in Figure 3. (Cache 3.2 MOPAC calculation). Unless the binding site is quite rigid for the size of a particular halide, halide anions tend to associate with receptors according to their basicity. (i.e. in the order of $\mathrm{F}^{-}>$ $\mathrm{Cl}^{-}>\mathrm{Br}^{-}>\mathrm{I}^{-}$)

We also investigated the binding of other anions with receptor 1 with fluorescence titration. Job plot experiments showed $1: 1$ binding stoichiometry for all kinds of anions

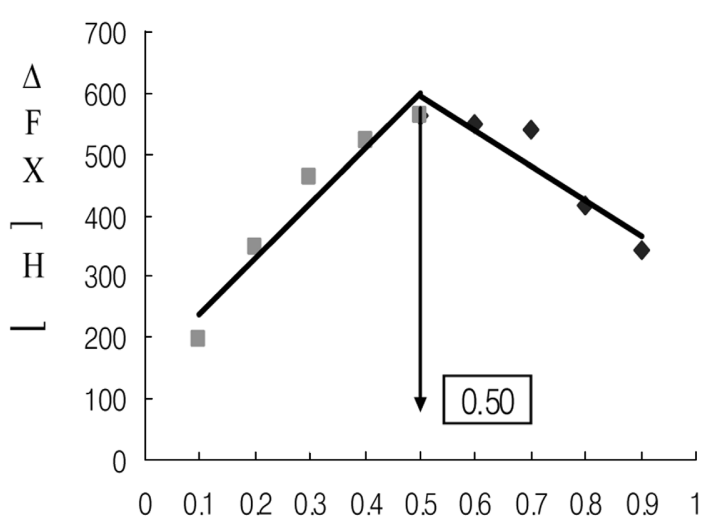

(a)

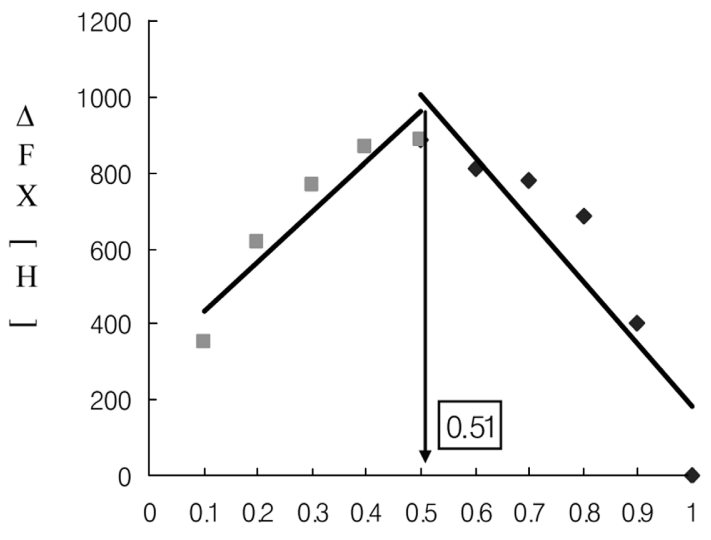

(b)

Figure 2. Job plot between the receptor $\mathbf{1}$ and iodide (a) and receptor $\mathbf{1}$ and isophthalate (b).

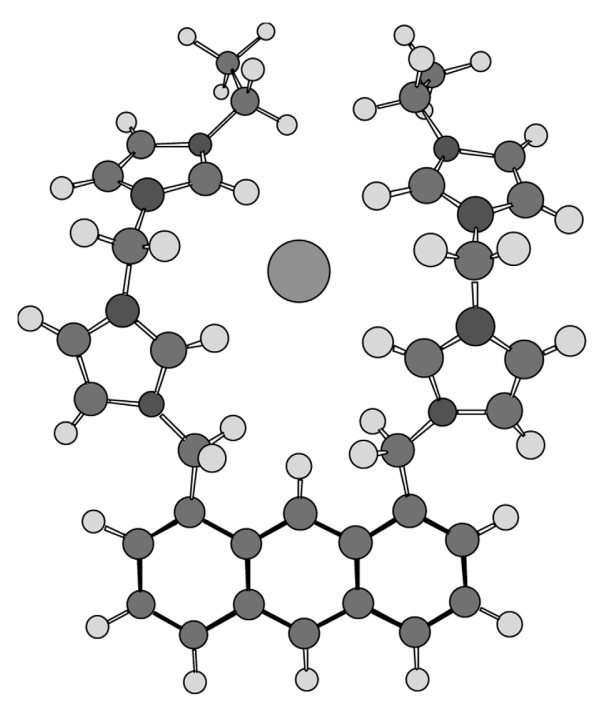

(a)

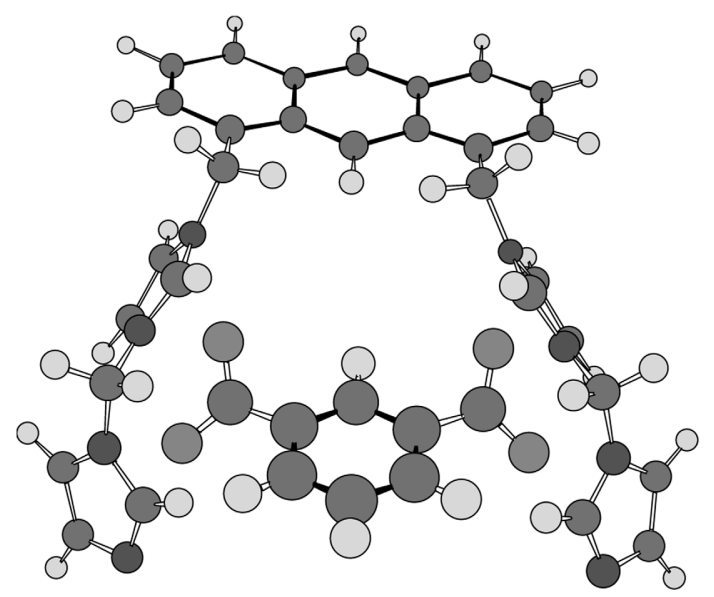

(b)

Figure 3. The energy minimized structure of $1: 1$ complex between receptor $\mathbf{1}$ and iodide (a) and receptor $\mathbf{1}$ and isophthalate (b). 
Table 1. Association Constants $\left(\mathrm{M}^{-1}\right)$ of receptor 1 with tetrabutylammonium anions in $10 \%$ DMSO in acetonitrile from fluorescence titration. The numbers in parenthesis are association constants in $10 \%$ DMSO- $\mathrm{d}_{6}$ in acetonitrile- $\mathrm{d}_{3}$ from ${ }^{1} \mathrm{H}$ NMR titration

\begin{tabular}{ll}
\hline Anion & Association constants $\left(\mathrm{K}_{\mathrm{a}}\right)$ \\
\hline $\mathrm{F}^{-}$ & $980 \pm 17$ \\
$\mathrm{Cl}^{-}$ & $330 \pm 13$ \\
$\mathrm{Br}^{-}$ & $140 \pm 18$ \\
$\mathrm{I}^{-}$ & $80 \pm 5(103 \pm 11)$ \\
$\mathrm{H}_{2} \mathrm{PO}_{4}{ }^{-}$ & $347 \pm 26$ \\
$\mathrm{HSO}_{4}{ }^{-}$ & $160 \pm 19$ \\
$\mathrm{C}_{6} \mathrm{H}_{5} \mathrm{CO}_{2}{ }^{-}$ & $110 \pm 20$ \\
$\mathrm{CH}_{3} \mathrm{CO}_{2}{ }^{-}$ & $280 \pm 15$ \\
$\mathrm{NO}_{3}{ }^{-}$ & $30 \pm 4$ \\
$\mathrm{CN}^{-}$ & $140 \pm 20$ \\
${ }^{-} \mathrm{O}_{2} \mathrm{CCO}_{2}^{-}\left(\mathrm{oxalate}^{-}\right.$ & $1400 \pm 150$ \\
${ }^{-} \mathrm{O}_{2} \mathrm{C}_{\left(\mathrm{CH}_{2}\right)_{2} \mathrm{CO}_{2}{ }^{-} \text {(succinate) }}$ & $1000 \pm 180$ \\
${ }^{-} \mathrm{O}_{2} \mathrm{C}_{\left(\mathrm{CH}_{2}\right)_{3} \mathrm{CO}_{2}{ }^{-} \text {(glutarate) }}$ & $1600 \pm 200$ \\
${ }^{-} \mathrm{O}_{2} \mathrm{C}\left(\mathrm{CH}_{2}\right)_{4} \mathrm{CO}_{2}{ }^{-}$(adipate) & $5300 \pm 350$ \\
$\mathrm{C}_{6} \mathrm{H}_{4}-1,3-\left(\mathrm{CO}_{2}{ }^{-}\right)_{2}$ (isophthalate) & $5000 \pm 250(2780 \pm 428)$ \\
$\mathrm{C}_{6} \mathrm{H}_{4}-1,4-\left(\mathrm{CO}_{2}{ }^{-}\right)_{2}$ (Terephthalate) & $1800 \pm 300$ \\
\hline
\end{tabular}

investigated irrespective of anion shapes. All anions studied showed only modest affinity toward the receptor $\mathbf{1}$. The results are summarized in Table 1.

As the receptor $\mathbf{1}$ is flexible, molecular modeling also showed that the receptor $\mathbf{1}$ could bind dicarboxylate. Therefore, we measured binding constants of various dicarboxylate with receptor $\mathbf{1}$. The tetrabutylammomium salts of various dicarboxylate were prepared by neutralizing the corresponding dicarboxylic acid with $1.0 \mathrm{M}$ tetrabutylammonium hydroxide in methanol solution, followed by vaccum-drying at $40-50{ }^{\circ} \mathrm{C}$ for $24 \mathrm{~h}$. Among the dicarboxylates we tested, isophthalate and adipate gave highest association constant $5000 \pm 350$ and $5300 \pm 350$. The distances between two carboxyl groups inside adipate and isophthalate are $6.0 \AA$ and $5.8 \AA$ respectively. From modeling (Figure 3), this distance is found to be close to largest size of dicarboxylate which the receptor 1 can bind 1 $: 1$ stoichiometry. The other dicarboxylates showed similar binding constants irrespective of distances of two carboxyl groups. The selectivity is low due to flexibility of receptor 1 . Job plot experiments showed $1: 1$ binding stoichiometry for all kinds of dicarboxylated investigated. The results are summarized in Table 1.

In summary, we have designed and synthesized fluorescent imidazolium receptor $\mathbf{1}$ which displays selectivity for fluoride and adipiate. However, their selectivity is not high due to flexibility of receptor $\mathbf{1}$.

\section{Experimental Section}

\section{Synthesis}

Compound 2: To a solution of $1 \mathrm{~g}$ imidazole in $15 \mathrm{~mL}$
DMF was added $105 \mathrm{mg}$ ( $1.5 \mathrm{eq}$.) of sodium hydride and 1.4 $\mathrm{mL}$ (1.5 eq.) bromochloromethane. After the reaction mixture was stirred for 3 hours, the solvent was evaporated in vacuo. Recrystallization in dichloromethane gave $700 \mathrm{mg}$ of compound 2 in $64 \%$ yield. ${ }^{1} \mathrm{H}$ NMR $\left(\mathrm{CDCl}_{3}\right) 7.6(\mathrm{~s}, 2 \mathrm{H})$ $7.0(\mathrm{~s}, 2 \mathrm{H}) 6.9(\mathrm{~s}, 2 \mathrm{H}) 5.9(\mathrm{~s}, 2 \mathrm{H}) ;{ }^{13} \mathrm{C} \mathrm{NMR}\left(\mathrm{CD}_{3} \mathrm{CN}\right) \delta$ 137.5, 130.1, 119.0, 56.0 HRMS (FAB) calculated for $\mathrm{C}_{7} \mathrm{H}_{8} \mathrm{~N}_{4} \mathrm{H}^{+}, 149.0827$; found for 149.0835 .

Compound 3: To a solution of $500 \mathrm{mg} 2$ in $10 \mathrm{~mL}$ of acetonitrile was added $75.5 \mu \mathrm{L}$ ( 0.3 eq.) of ethyl bromide and refluxed for 3 hours. After all of acetonitrile was evaporated, the mixture was dissolved in $20 \mathrm{~mL}$ of distilled water. The water solution was extracted with $150 \mathrm{~mL}$ of dichloromethane 10 times to remove unreacted 2. Evaporation of water in vacuo and recrystallization of the mixture with $5 \%$ methanol in acetonitrile gave $97 \mathrm{mg}$ of compound $\mathbf{3}$ in $37 \%$ yield. ${ }^{1} \mathrm{H}$ NMR $\left(\mathrm{CD}_{3} \mathrm{CN}\right) 9.83(\mathrm{~s}, 1 \mathrm{H}) 8.21(\mathrm{~s}, 1 \mathrm{H})$ $7.86(\mathrm{~d}, J=2,1 \mathrm{H}) 7.60(\mathrm{~d}, 1 \mathrm{H}) 7.44(\mathrm{~d}, J=2,1 \mathrm{H}) 6.98 \mathrm{(s}$, 1H) $6.60(\mathrm{~s}, 2 \mathrm{H}) 4.18(\mathrm{q}, J=6,2 \mathrm{H}) 1.45(\mathrm{t}, J=6,3 \mathrm{H}) ;{ }^{13} \mathrm{C}$ NMR $\left(\mathrm{CD}_{3} \mathrm{CN}\right) \delta 138.4,136.8,130.0,122.9,122.2,119.8$, 57.2, 45.6, 14.6 HRMS (FAB) M-Br calculated for $\mathrm{C}_{9} \mathrm{H}_{13} \mathrm{~N}_{4}$, 177.1140; found for 177.1158 .

Compound 1: To a solution of $100 \mathrm{mg}$ compound 3 in 8 $\mathrm{mL}$ of acetonitrile was added $71 \mathrm{mg}$ 1,8-bis(bromomethyl)anthracene and refluxed for 4 hours. The resulting solid was filtered and redissolved in $5 \mathrm{~mL}$ of water. To this water solution, $234 \mathrm{mg}$ of hexafluorophospahte was added and stirred for an hour. Filtration of the precipitated solid gave $147 \mathrm{mg}$ of compound 1 in $66 \%$ yield. ${ }^{1} \mathrm{H}$ NMR $\left(\mathrm{CD}_{3} \mathrm{CN}\right)$ $8.79 \mathrm{~s}, 1 \mathrm{H}) 8.72(\mathrm{~s}, 2 \mathrm{H}) 8.69 \mathrm{~s}, 2 \mathrm{H}) 8.44(\mathrm{~s}, 1 \mathrm{H}) 8.27 \mathrm{~s}$, 1H) $8.23(\mathrm{~s}, 1 \mathrm{H}) 7.60(\mathrm{~m}, 12 \mathrm{H}) 6.30(\mathrm{~s}, 4 \mathrm{H}) 5.99(\mathrm{~s}, 4 \mathrm{H}) 4.28$ (q, $4 \mathrm{H}, J=7.3) 1.51(\mathrm{t}, 6 \mathrm{H}, J=7.3) ;{ }^{13} \mathrm{C}$ NMR $\left(\mathrm{CD}_{3} \mathrm{CN}\right) \delta$ $192.5,137.3,136.6,132.2,130.9,129.7,129.5,128.7$, 125.8, 124.3, 123.6, 122.8, 122.5, 59.0, 51.5, 45.8, 31.6, 14.2 HRMS (FAB) M-PF 6 calculated for $\mathrm{C}_{34} \mathrm{H}_{38} \mathrm{~N}_{8} \mathrm{P}_{3} \mathrm{~F}_{18}$, 993.2145; found for 993.2183 .

\section{References}

1. (a) Gale, P. A. Coord. Chem. Rev. 2003, 240, 191; (b)Beer, P. D.; Gale, P. A. Angew. Chem. Int. Ed. Engl. 2001, 40, 486; (c) Gale, P. A. Coord. Chem. Rev. 2001, 213, 79; (d) Gale, P. A. Coord. Chem. Rev. 2000, 199, 181.

2. (a) Martínez-Máñez, R.; Sancenón, F. Chem. Rev. 2003, 103, 4419; (b) Keefe, M. H.; Benkstein, K. D.; Hupp, J. T. Coord. Chem. Rev. 2000, 205, 201; (c) De Silva, A. P.; Gunaratne, H. Q.; Gunnlaugsson, N. T.; Huxley, A. J. M.; McCoy, C. P.; Rademacher, J. T.; Rice, T. E. Chem. Rev. 1997, 97, 1515.

3. (a) Llinares, J. M.; Powell, D.; Bowman-James, K. Coord. Chem. Rev. 2003, 240, 57; (b) Bondy, C. R.; Loeb, S. J. Coord. Chem. Rev. 2003, 240, 77; (c) Ilioudis, C. A.; Steed, J. W. J. Supramol. Chem. 2001, 1, 165.

4. (a) Ihm, H.; Yun, S.; Kim, H. G.; Kim, J. K.; Kim, K. S. Org. Lett. 2002, 4, 2897; (b) Yun, S.; Ihm, H.; Kim, H. G.; Lee, C.-I.; Indrajit, B.; Oh, K. S.; Gong, Y. J.; Lee, J. W.; Yoon, J.; Lee, H. C.; Kim, K. S. J. Org. Chem. 2003, 68, 2467; (c) Chellappan, K.; Singh, N. J.; Hwang, I.-C.; Lee, J. W.; Kim, K. S. Angew. Chem. Int. Ed. 2005, 44, 2.

5. (a) Kim, S. K.; Singh, N. J.; Kim, S. J.; Kim, H. G.; Kim, J. K.; Lee, J. W.; Kim, K. S.; Yoon, J. J. Org. Lett. 2003, 5, 2083; (b) 
Yoon, J.; Kim, S. K.; Singh, N. J.; Lee, J. W.; Yang, Y. J.; Chellappan, K.; Kim, K. S. J. Org. Chem. 2004, 69, 581.

6. Kim, S. K.; Kang, B.-G.; Koh, H. S.; Yoon, Y. J.; Jung, S. J.; Jeong, B.; Lee, K.-D.; Yoon, J. J. Org. Lett. 2004, 6, 4655.

7. In, S.; Kang, J. Supramolecular Chem. in press.
8. Hynes, M. J. J. Chem. Soc. Dalton Trans. 1993, 311

9. Job, P. Ann. Chim. 1928, 9, 113.

10. Benesi, H.; Hildebrand, H. J. Am. Chem. Soc. 1949, 71, 2703.

11. Fabbrizzi, L.; Poggi, A. Chem. Soc. Rev. 1995, 197. 